Article

\title{
Ring Enlargement of Methylcyclopentane over Pt/(HZSM-48+pseudoboehmite) Catalysts
}

\author{
Youri Park ${ }^{1}$, Yong Cheol Kim ${ }^{1}$, Jinhan Kim ${ }^{1}$, Young-Kwon Park ${ }^{2}$, Yun Seok Choi ${ }^{3}$, \\ Ji Man Kim ${ }^{3}$ and Jong-Ki Jeon ${ }^{1, *}$ \\ 1 Department of Chemical Engineering, Kongju National University, Cheonan 31080, Korea; \\ yuri.bak95@smail.kongju.ac.kr (Y.P.); yck@koreapetroleum.com (Y.C.K.); sihouette87@naver.com (J.K.) \\ 2 School of Environmental Engineering, University of Seoul, Seoul 02504, Korea; catalica@uos.ac.kr \\ 3 Department of Chemistry, Sungkyunkwan University, Suwon 16419, Korea; skkuman10@naver.com (Y.S.C.); \\ jimankim@skku.edu (J.M.K.) \\ * Correspondence: jkjeon@kongju.ac.kr; Tel.: +82-41-521-9363
}

Received: 29 May 2019; Accepted: 10 June 2019; Published: 13 June 2019

check for updates

\begin{abstract}
Platinum catalysts loaded on a hybrid support, composed of HZSM-48 and pseudoboehmite, were applied to the synthesis of benzene through methylcyclopentane (MCP) reforming in order to investigate the effect of the addition of pseudoboehmite to $\mathrm{Pt} / \mathrm{HZSM}-48$ for ring-enlargement reaction. A total of $0.5 \mathrm{wt} \%$ of platinum was impregnated on the hybrid support by using the incipient wetness method. Catalyst characterization was performed with nitrogen sorption, X-ray diffraction, temperature-programmed desorption of $\mathrm{NH}_{3}$, and infrared spectroscopy of adsorbed pyridine. It was found that mesoporous structures were well-developed in Pt/(HZSM-48 + pseudoboehmite) catalyst as a result of the pseudoboehmite addition, of which the average pore size was in the range of 7-8 nm. The presence of pseudoboehmite in the catalyst increases the total amount of acid sites and weakens the acid strength, compared with those of the Pt/HZSM-48 catalyst. Lewis acid sites were more abundant than Brönsted acid sites over the Pt/(HZSM-48+pseudoboehmite) catalysts. It was found that selectivity to the ring-enlargement reaction is dominant over selectivity to the ring-opening reaction over the Pt/(HZSM-48 + pseudoboehmite) catalysts. The benzene yield over Pt/(HZSM-48 + pseudoboehmite, $1: 1$ ) catalyst reached $65.1 \%$ at $450{ }^{\circ} \mathrm{C}$ and $0.3 \mathrm{~h}^{-1}$. As well as being influenced by the mesoporous structure, the higher activity and selectivity in MCP reforming was also determined by appropriate acidity of the Pt/(HZSM-48 + pseudoboehmite) catalysts.
\end{abstract}

Keywords: methylcyclopentane; ring-enlargement; platinum; HZSM-48; pseudoboehmite

\section{Introduction}

Benzene, toluene, and xylene (BTX) are valuable organic chemicals. Traditionally, BTX has been produced primarily through petroleum-based processes, such as steam cracking and catalytic reforming of naphtha. Recently, the diversification of BTX sources has attracted much attention with an increased demand for BTX [1]. In the petrochemical process, a large amount of methylcyclopentane (MCP) is produced as a by-product, and the process of producing benzene from MCP has been steadily becoming important [2-7]. The reforming of MCP is known to be a combination of three types of competing reactions over the noble metal/solid acid catalysts as follows [2,8-13]: Conversion to cyclohexane and benzene by ring enlargement (RE), conversion to $n$-hexane and iso-hexane via ring opening (RO), and generation of light molecules that contain less than 6 carbon atoms by cracking. Product selectivity is known to be related to the nature of the catalyst and the operating conditions [14].

In general, the ring enlargement of $\mathrm{MCP}$ is known as a bifunctional reaction that requires metal and acid sites [4]. In dual functional catalysts, the active metal sites promote hydrogenation and 
dehydrogenation, while the acid sites promote skeletal isomerization. MCP, the reactant, goes through adsorption, surface reaction, and desorption at two types of independent active sites to form olefin intermediates, which produce cyclohexane and benzene by their mutual reaction. Cyclohexane is further dehydrogenated and converted to benzene.

Amorphous oxide, zeolite, mesoporous material, and hybrid supports composed of amorphous oxide and zeolite have been studied as general supports for MCP reforming catalysts. $\mathrm{Al}_{2} \mathrm{O}_{3}, \mathrm{SiO}_{2}$, and $\mathrm{ZrO}_{2}-\mathrm{SiO}_{2}$ have been used as amorphous supports [12,13,15-18]; and Y zeolite, HZSM-5, mordenite, beta zeolite, $\mathrm{L}$ zeolite, and $\mathrm{AlPO}_{4}$ have been applied as zeolite supports $[1,4,5,8,9,13]$. Recently, studies on mesoporous materials, such as SBA-15 and MCF-17, have been reported [2,3]. As active metal sites that play a role of hydrogenation/dehydrogenation, precious metals, such as palladium, platinum, iridium, and rhodium, are mainly used in the form of a single metal or bimetal [9,10,12,15-17,19-21]. Catalysts to which $\mathrm{Ni}$ and $\mathrm{W}$ are applied have also been reported [3,12].

Recently, studies on hybrid supports composed of zeolite and amorphous oxide in hydrodesulfurization, hydrocracking, and catalytic cracking have been conducted [6,7]. Among the amorphous oxides used in hybrid supports, alumina has various advantages $[18,22]$. Alumina acts as an inorganic binder using its strong mechanical strength while at the same time performing as a catalyst with acid sites. Therefore, in the catalytic cracking reaction, the alumina matrix can exhibit a pre-cracking effect that is independent of the zeolite component. Moreover, alumina is known to protect the zeolite component from hydrothermal decomposition during catalyst regeneration. Therefore, the alumina matrix is considered to be effective in the aromatization reaction at high temperatures [18].

ZSM-48 contains a 10-membered ring channel structure with a pore diameter of $0.56 \mathrm{~nm} \times 0.53 \mathrm{~nm}$ and is reported to be an acid support of a catalyst for the hydroisomerization reaction of n-alkane [23]. To the best of our knowledge, ZSM-48 was utilized in the MCP reforming process for the first time in this study, in which a hybrid material that combines HZSM-48 zeolite and pseudoboehmite is used as a catalyst support. The present study focused elucidating the performance of a catalyst that has platinum impregnated on hybrid supports composed of zeolite and pseudoboehmite as a catalyst for ring enlargement (RE) of MCP to selectively produce benzene. The characteristics of the catalyst were analyzed by $\mathrm{N}_{2}$ adsorption-desorption, $\mathrm{X}$-ray diffraction (XRD), temperature-programmed desorption of $\mathrm{NH}_{3}\left(\mathrm{NH}_{3}-\mathrm{TPD}\right)$, and Fourier transform infrared spectroscopy of adsorbed pyridine (Pyridine-FTIR). The effects of the catalyst on MCP conversion, selectivity to benzene, and yield of benzene were assessed after carrying out MCP reforming in a fixed bed reactor.

\section{Results and Discussion}

\subsection{Characterization of Catalysts}

Figure 1 shows the XRD patterns for the Pt loaded catalysts and supports (HZSM-48 and pseudopoehmite). As shown in Figure 1a, the XRD pattern of HZSM-48 zeolite, prepared in this study, has two distinct peaks at 22 and 25 degrees, which were found to match well with the XRD patterns reported in the literature [23]. No clear peaks were detected in the XRD patterns of pseudobohemite (Figure 1e). Also, no characteristic peaks related on platinum species were observed in the Pt/(HZSM-48+pseudoboehmite) catalysts (Figure 1b-d), which was probably attributed to the small amount of platinum $(0.5 \mathrm{wt} \%)$. As expected, with increasing the content of pseudoboehmite in the Pt/(HZSM- 48 + pseudoboehmite) catalysts, the intensity of the characteristic peaks in the XRD patterns of HZSM-48 decreased.

As shown in the scanning electron microscope (SEM) image (Figure 2a), HZSM-48 sample exhibits ellipsoid morphology, and the particle diameter of HZSM-48 is in a range of 1-3 $\mu \mathrm{m}$, which is in good agreement with the literatures reported [24]. The SEM image of pseudoboehmite (Figure 2b) shows an aggregate of the irregular shaped particles of several tens of micrometers in size. In the case of the $\mathrm{Pt} /($ HZSM-48 + pseudoboehmite,1:1) sample (Figure 2c), the HZSM-48 particles can be found on the 
pseudoboehmite surface. In this sample, smaller particles of $3 \mu \mathrm{m}$ or less are confirmed to have the same morphology as HZSM-48 particles.

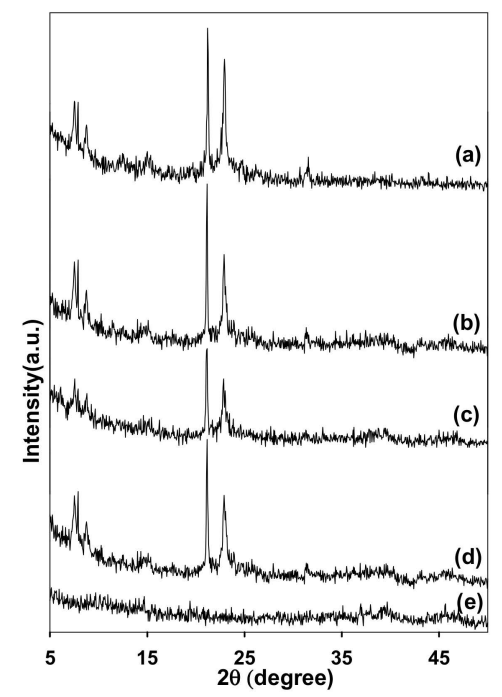

Figure 1. X-ray diffraction (XRD) patterns of (a) HZSM-48, (b) Pt/(HZSM-48 + pseudoboehmite, 1:1), (c) $\mathrm{Pt} /(\mathrm{HZSM}-48$ + pseudoboehmite, 1:2), (d) spent catalyst of Pt/(HZSM-48 + pseudoboehmite, 1:1), (e) pseudoboehmite.

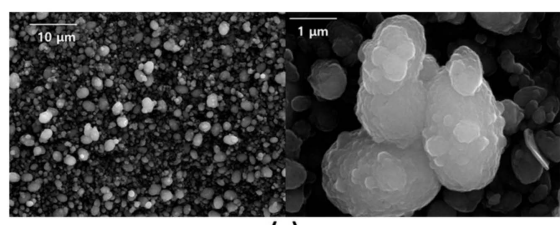

(a)

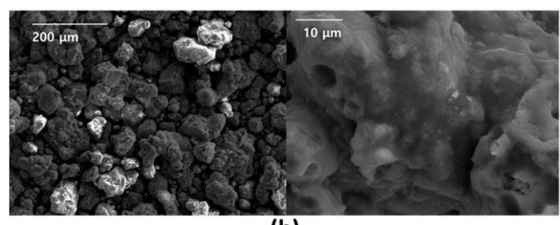

(b)

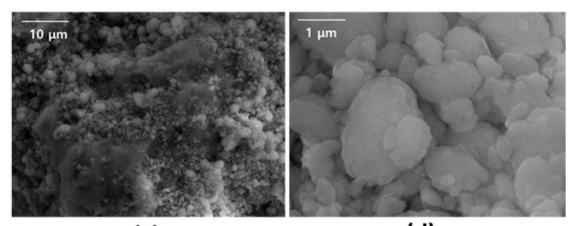

(c)

(d)

Figure 2. Scanning electron microscope (SEM) images of (a) HZSM-48, (b) pseudoboehmite, (c) $\mathrm{Pt} /(\mathrm{HZSM}-48+$ pseudoboehmite, 1:1), (d) the portion corresponding to Pt/HZSM-48 from (c).

Figure 3 shows the representative transmission electron microscope (TEM) images of Pt/HZSM-48 and Pt/(HZSM-48 + pseudoboehmite, 1:1). As shown in Figure 3, Pt nanoparticles were found both on the pseudoboehmite and on the HZSM- 48 surfaces. The average sizes of Pt particles are in the range of $5-15 \mathrm{~nm}$ and in the range of 3-10 nm on Pt/HZSM-48 and Pt/(HZSM-48 + pseudoboehmite, 1:1) samples, respectively, suggesting that nanosized Pt particles are highly dispersed not only on HZSM-48 but also on pseudoboehmite.

The metallic properties of the reduced catalysts were determined by chemisorption of carbon monoxide. The average diameter of the Pt particle is $9.0 \mathrm{~nm}$ and $6.3 \mathrm{~nm}$ on Pt/HZSM-48 and $\mathrm{Pt} /(\mathrm{HZSM}-48$ + pseudoboehmite, 1:1), respectively. This result is consistent with the Pt particle diameter observed in TEM images (Figure 3). 

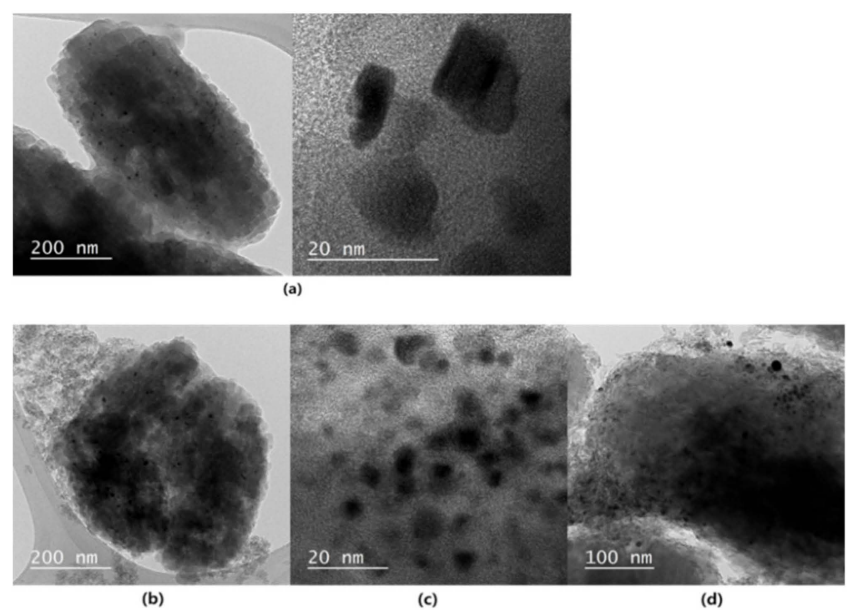

Figure 3. Transmission electron microscope (TEM) images of (a) Pt/HZSM-48, (b) Pt/(HZSM-48 + pseudoboehmite, 1:1), (c) the portion corresponding to $\mathrm{Pt} / \mathrm{HZSM}-48$ from $\mathrm{Pt} /(\mathrm{HZSM}-48+$ pseudoboehmite, 1:1), and (d) the portion corresponding to Pt/pseudoboehmite from Pt/(HZSM-48 + pseudoboehmite, 1:1).

$\mathrm{N}_{2}$ adsorption-desorption isotherms of the catalysts (Figure 4) show that those of the HZSM-48 and Pt/HZSM-48 catalysts correspond to type-I of the International Union of Pure and Applied Chemistry (IUPAC) classification, which indicates that the pores of both catalysts are composed of micropores [25]. Pseudoboehmite shows a type IV absorption-desorption isotherm of the IUPAC classification [25]. That is, the amount of adsorption increases rapidly and shows a hysteresis phenomenon when the $\mathrm{P} / \mathrm{P}_{0}$ range is $0.4-0.9$, and these are characteristics of mesoporous materials. Mesoporous structures, resulted from the mesoporores of pseudoboehmite, were found to be well-developed in the Pt/(HZSM- $48+$ pseudoboehmite) samples. The pore size distribution curves in Figure 5 indicates that the average mesopores sizes of the Pt/(HZSM-48 + pseudoboehmite) catalysts were in a range of 7.0-8.0 nm (Table 1), which were very similar with that of pseudoboehmite. These results clearly indicate that the pseudoboehmite resulted in the development of mesopores in the mixed support (HZSM-48 + pseudoboehmite). The $\mathrm{N}_{2}$ isotherms of Pt/(HZSM-48 + pseudoboehmite) samples (Figure 4) also show a sharp rise in the adsorbed amount near saturation, which is known to be associated with condensation in inter-particle voids [26]. The pore size distribution peaks (>100 nm) in of Pt/(HZSM-48 + pseudoboehmite) samples (Figure 5) can be correlated with their inter-particle porosity. The reason why the total pore volume of $\mathrm{Pt} /(\mathrm{H}-\mathrm{ZSM}-48+$ pseudoboehmite, 1:2) is unusually high can be attributed to inter-particle porosity due to decrease of compaction between HZSM-48 and pseudoboehmite.

Table 1. Surface area, pore volume and average pore diameter of various catalysts.

\begin{tabular}{|c|c|c|c|c|c|}
\hline Catalysts & $\mathrm{S}_{\mathrm{BET}}{ }^{\mathrm{a}}\left(\mathrm{m}^{2} / \mathrm{g}\right)$ & $V_{t}^{b}\left(\mathrm{~cm}^{3} / g\right)$ & $\mathrm{V}_{\text {micro }}{ }^{\mathrm{c}}\left(\mathrm{cm}^{3} / \mathrm{g}\right)$ & $V_{\text {meso }}{ }^{d}\left(\mathrm{~cm}^{3} / \mathrm{g}\right)$ & $D_{p}^{e}(n m)$ \\
\hline HZSM-48 & 241 & 0.18 & 0.10 & 0.07 & - \\
\hline $\mathrm{Pt} / \mathrm{HZSM}-48$ & 218 & 0.16 & 0.09 & 0.07 & - \\
\hline $\begin{array}{c}\text { Pt/(HZSM-48 + } \\
\text { Pseudoboehmite, 1:1) }\end{array}$ & 221 & 0.86 & 0.24 & 0.62 & 8.04 \\
\hline $\begin{array}{c}\text { Pt/(HZSM-48 + } \\
\text { Pseudoboehmite, 1:2) }\end{array}$ & 243 & 1.22 & 0.34 & 0.88 & 7.04 \\
\hline Pseudoboehmite & 328 & 0.92 & 0.38 & 0.54 & 8.04 \\
\hline
\end{tabular}

${ }^{a}$ Surface area determined by Brunauer-Emmet-Teller (BET) method; ${ }^{b}$ Pore volume measured at $\mathrm{p} / \mathrm{p}_{0}=0.99 ;{ }^{\mathrm{c}}$ Micropore volume calculated by the $t$-method; ${ }^{d}$ Difference between the total pore volume and the micropore volume; ${ }^{\mathrm{e}}$ Average diameter of mesopore determined by Barrett-Joyner-Halenda (BJH) method. 


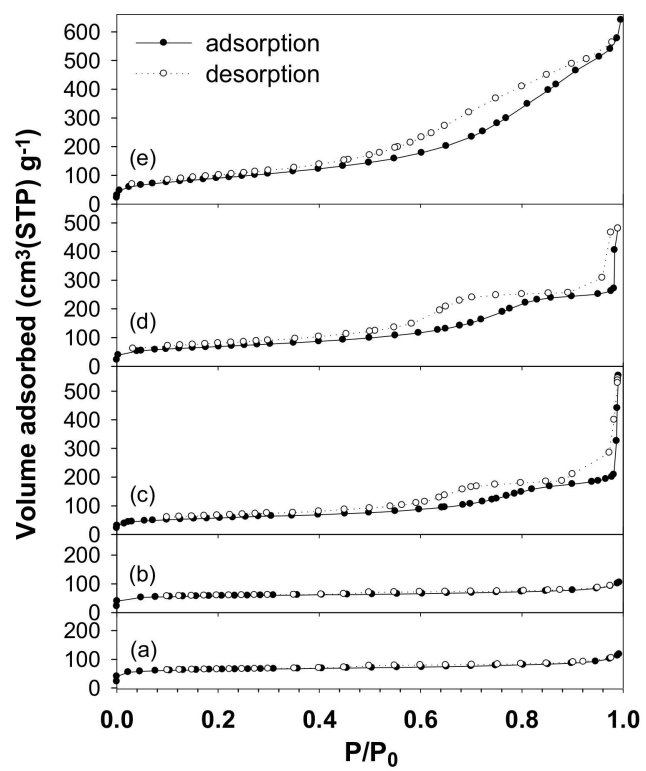

Figure 4. $\mathrm{N}_{2}$ adsorption-desorption isotherms of (a) HZSM-48, (b) Pt/HZSM-48, (c) Pt/(HZSM-48 + pseudoboehmite, 1:1), (d) Pt/(HZSM-48 + pseudoboehmite, 1:2), (e) pseudoboehmite.

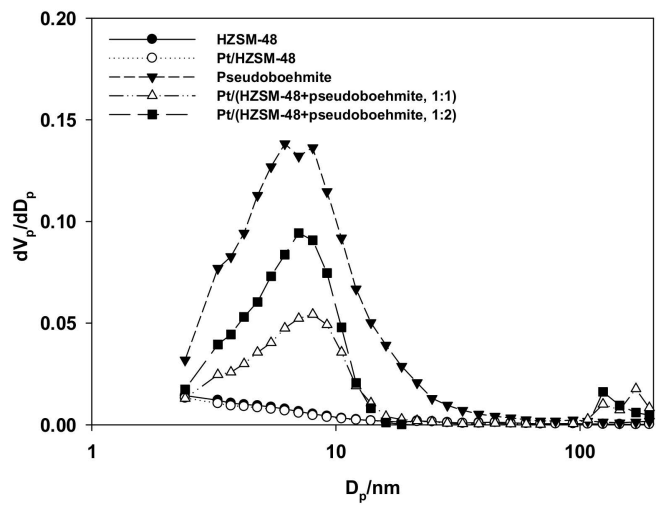

Figure 5. Pore size distribution of various catalysts.

Figure 6 shows the $\mathrm{NH}_{3}$-TPD profile for the present catalysts. The $\mathrm{NH}_{3}$-TPD profile of the Pt/HZSM-48 sample shows two peaks at $165^{\circ} \mathrm{C}$ and $355^{\circ} \mathrm{C}$ (Figure 6a), which correspond to weak acid sites and medium strength acid sites, respectively [24]. On the other hand, the $\mathrm{NH}_{3}$-TPD curve of pseudoboehmite showed a broad peak at $210^{\circ} \mathrm{C}$ (Figure $6 \mathrm{~d}$ ), indicating that the acid sites with weak strength are mainly developed in the pseudoboehmite. Figure $6 \mathrm{~b}, \mathrm{c}$ show that the amount of acid sites between 150 and $325{ }^{\circ} \mathrm{C}$ increased in the $\mathrm{Pt} /(\mathrm{HZSM}-48 \mathrm{v}+$ pseudoboehmite), which were probably due to the presence of the pseudoboehmite. The most remarkable effect of pseudoboehmite is the shift of the $\mathrm{NH}_{3}$-TPD peak corresponding to the acid site with medium strength. The temperature corresponding to the medium strength acid site of the Pt/HZSM- 48 sample was $355{ }^{\circ} \mathrm{C}$, whereas mixing the pseudoboehmite to the support shifted the peak temperature to the range of $310-320^{\circ} \mathrm{C}$. This means that the acid strength was weakened by mixing the pseudobehmite and HZSM-48. Table 2 also indicates that the total amounts of acid sites of $\mathrm{Pt} /(\mathrm{HZSM}-48+$ pseudoboehmite $)$ catalysts are slightly larger than that of $\mathrm{Pt} / \mathrm{HZSM}-48$. From the $\mathrm{NH}_{3}-\mathrm{TPD}$, the mixed support, composed with pseudoboehmite and HZSM-48, slightly increases the total amount of acid sites and weakens the acid strength, compared with those of HZSM-48. 


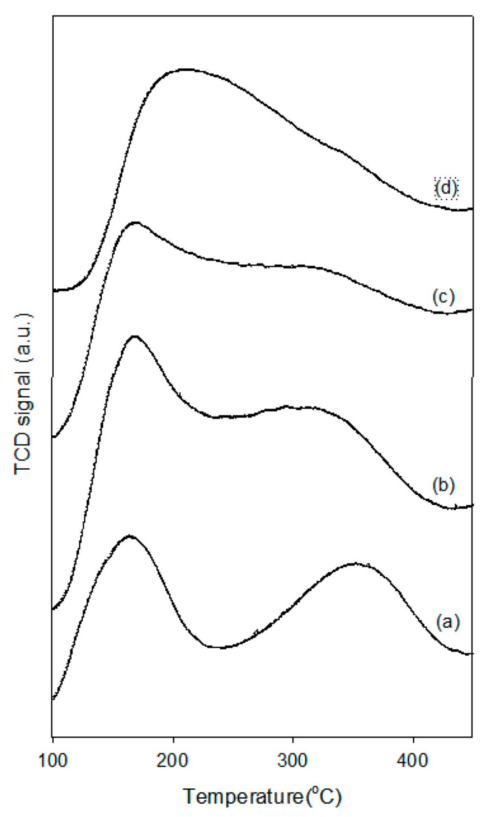

Figure 6. $\mathrm{NH}_{3}-\mathrm{TPD}$ of various catalysts (a) Pt/HZSM-48, (b) Pt/(HZSM-48 + pseudoboehmite, 1:1), (c) $\mathrm{Pt} /\left(\mathrm{HZSM}-48+\right.$ pseudoboehmite, 1:2), (d) pseudoboehmite (calcined at $\left.400{ }^{\circ} \mathrm{C}\right)$.

Table 2. Amount of $\mathrm{NH}_{3}$ desorbed during $\mathrm{NH}_{3}-\mathrm{TPD}$ on various catalysts.

\begin{tabular}{cc}
\hline Catalysts & Amount of $\mathbf{N H}_{\mathbf{3}}$ Desorbed (mmol/g) \\
\hline Pt/HZSM-48 & $5.34 \times 10^{2}$ \\
pseudoboehmite & $5.60 \times 10^{2}$ \\
$\mathrm{Pt} /(\mathrm{HZSM}-48+$ pseudoboehmite, $1: 1)$ & $5.52 \times 10^{2}$ \\
$\mathrm{Pt} /(\mathrm{HZSM}-48+$ pseudoboehmite, $1: 2)$ & $5.45 \times 10^{2}$ \\
\hline
\end{tabular}

The results of pyridine-FTIR are shown in Figures 7 and 8 . The pyridine-FTIR spectra, obtained by adsorbing pyridine on the Pt/HZSM-48 catalyst and then raising the temperature in a vacuum, show that the three peaks at 1450,1492 and $1545 \mathrm{~cm}^{-1}$ did not decrease notably even when the desorption temperature was raised to $300{ }^{\circ} \mathrm{C}$ (Figure 7). The peaks at 1450 and $1545 \mathrm{~cm}^{-1}$ correspond to Lewis acid sites and Brönsted acid sites, respectively $[27,28]$. The peak shown at $1492 \mathrm{~cm}^{-1}$ is known to be a peak at the Brönsted acid sites and Lewis acid sites, simultaneously. It was confirmed that both the Lewis acid sites and the Brönsted acid sites were present on the Pt/HZSM-48 catalyst.

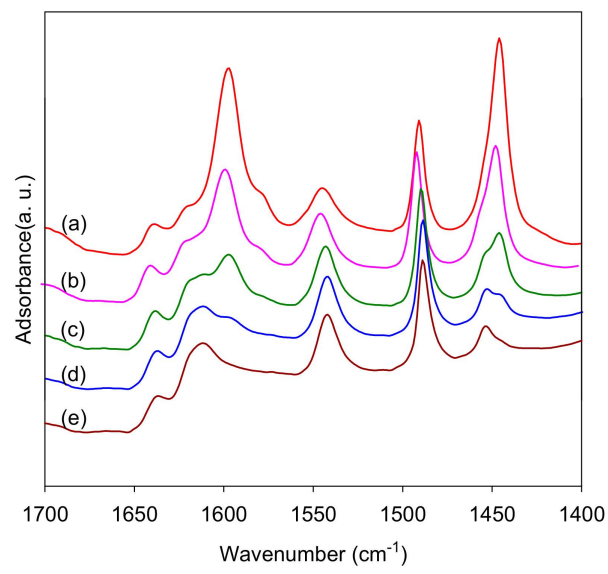

Figure 7. Fourier Transform Infrared (FT-IR) spectra of pyridine adsorbed over Pt/HZSM-48 catalyst under $10^{-3}$ torr at (a) $100{ }^{\circ} \mathrm{C}$, (b) $150{ }^{\circ} \mathrm{C}$, (c) $200{ }^{\circ} \mathrm{C}$, (d) $250{ }^{\circ} \mathrm{C}$, and (e) $300{ }^{\circ} \mathrm{C}$. 


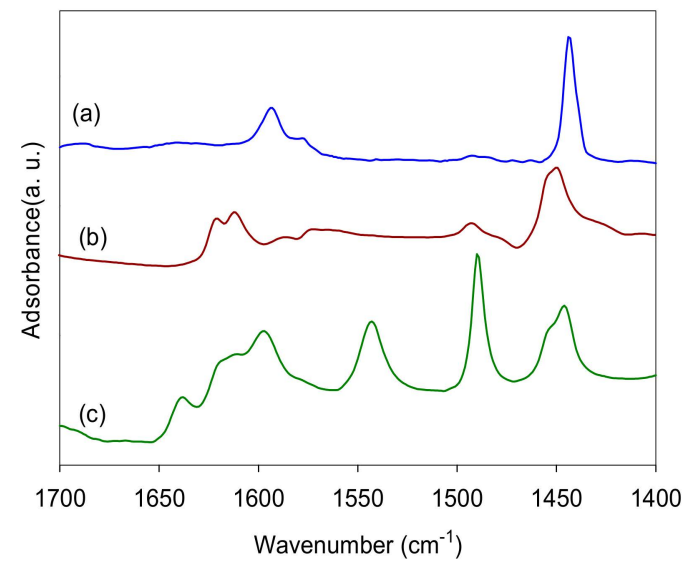

Figure 8. Pyridine-FTIR under $10^{-3}$ torr at $200{ }^{\circ} \mathrm{C}$ over (a) Pt/(HZSM-48 + pseudoboehmite,1:1) (b) pseudoboehmite, (c) Pt/HZSM-48.

The pyridine-FTIR spectra of three samples (Pt/(HZSM-48 + pseudoboehmite 1:1), pseudoboehmite, and Pt/HZSM-48) at $200^{\circ} \mathrm{C}$ under vacuum are shown in Figure 8. In the Pt/(HZSM-48 + pseudoboehmite, 1:1) catalyst, Lewis acid sites $\left(1450 \mathrm{~cm}^{-1}\right)$ were more abundant than Brönsted acid sites $\left(1540 \mathrm{~cm}^{-1}\right)$, and such a characteristic is similar to the pseudoboehmite.

\subsection{Ring Enlargement Reaction of Methylcyclopentane}

Catalytic performances of Pt/HZSM-48, Pt/pseudoboehmite and Pt/(HZSM-48+ pseudoboehmite) samples in the methylcyclopentane ring enlargement reaction were investigated, and the product distribution and selectivity for the desired benzene at various temperatures were determined. In the case of $\mathrm{Pt} /$ pseudoboehmite catalyst, ring-enlargement of MCP is suppressed and the main reaction is ring opening at high temperature (Figure 9 and Table 3). MCP can be converted into a mixture of the corresponding paraffins with selectivity $73 \%$ at $450{ }^{\circ} \mathrm{C}$. The results of the effect of temperature on the conversion of methylcyclopentane over the Pt/HZSM-48 and Pt/(HZSM-48+pseudoboehmite) samples (Figure 9) show that the conversion over the Pt/HZSM-48 catalyst was higher than that over the Pt/(HZSM-48+pseudoboehmite) catalysts at relatively low temperatures $\left(<350^{\circ} \mathrm{C}\right)$. However, the methylcyclopentane conversion over the Pt/(HZSM-48+pseudoboehmite) catalysts was higher than that over the $\mathrm{Pt} / \mathrm{HZSM}-48$ catalyst at higher temperatures $\left(>350^{\circ} \mathrm{C}\right)$. The conversion for the two kinds of Pt/(HZSM-48+pseudoboehmite) catalysts, which reached close to $94 \%$, was almost the same at a temperature range of $250-450{ }^{\circ} \mathrm{C}$.

Table 3. Conversion and selectivity in methylcyclopentane reforming over various catalysts reaction condition: $\mathrm{H}_{2} / \mathrm{MCP}$ (mole/mole) 10, pressure $1 \mathrm{~atm}$, WHSV $0.3 \mathrm{~h}^{-1}$, and T-O-S $3 \mathrm{~h}$.

\begin{tabular}{|c|c|c|c|c|c|c|c|c|}
\hline \multirow{3}{*}{ Catalysts } & \multirow{3}{*}{ Temp. $\left({ }^{\circ} \mathrm{C}\right)$} & \multirow{3}{*}{ Conv. (\%) } & \multicolumn{6}{|c|}{ Selectivity (\%) } \\
\hline & & & \multicolumn{3}{|c|}{ Ring-Opening } & \multicolumn{2}{|c|}{ Ring-Enlargement } & \multirow{2}{*}{ Cracking } \\
\hline & & & 2-MP ${ }^{a}$ & 3-MP b & n-Hexane & Benzene & Cyclo-Hexane & \\
\hline \multirow{4}{*}{$\mathrm{Pt} / \mathrm{HZSM}-48$} & 300 & 36.4 & 40.0 & 21.8 & 22.7 & 12.3 & 1.6 & 1.6 \\
\hline & 350 & 71.8 & 16.4 & 9.4 & 8.5 & 54.2 & 5.6 & 5.4 \\
\hline & 400 & 84.5 & 8.4 & 4.8 & 4.8 & 64.7 & 0.0 & 15.8 \\
\hline & 450 & 83.0 & 6.1 & 3.7 & 9.2 & 50.1 & 0.0 & 25.5 \\
\hline \multirow{4}{*}{$\begin{array}{c}\text { Pt/(HZSM-48+ } \\
\text { pseudoboehmite, 1:1) }\end{array}$} & 300 & 15.6 & 10.0 & 6.0 & 5.0 & 41.9 & 34.8 & 2.3 \\
\hline & 350 & 55.8 & 8.6 & 5.2 & 4.8 & 76.4 & 2.4 & 2.2 \\
\hline & 400 & 89.5 & 9.5 & 5.6 & 5.7 & 72.2 & 0.6 & 5.2 \\
\hline & 450 & 91.5 & 6.2 & 3.5 & 3.7 & 71.1 & 0.6 & 10.6 \\
\hline \multirow{4}{*}{$\begin{array}{c}\text { Pt/(HZSM-48+ } \\
\text { pseudoboehmite, 1:2) }\end{array}$} & 300 & 14.4 & 11.9 & 7.2 & 7.0 & 47.5 & 22.8 & 3.6 \\
\hline & 350 & 58.0 & 16.5 & 10.1 & 9.7 & 59.2 & 1.2 & 2.2 \\
\hline & 400 & 91.4 & 10.9 & 6.3 & 7.5 & 67.8 & 0.3 & 5.7 \\
\hline & 450 & 94.0 & 5.9 & 3.7 & 2.8 & 67.0 & 0.8 & 12.3 \\
\hline Pt/pseudoboehmite & 450 & 40.7 & 31.5 & 20.4 & 20.7 & 25.7 & 0.4 & 1.3 \\
\hline
\end{tabular}




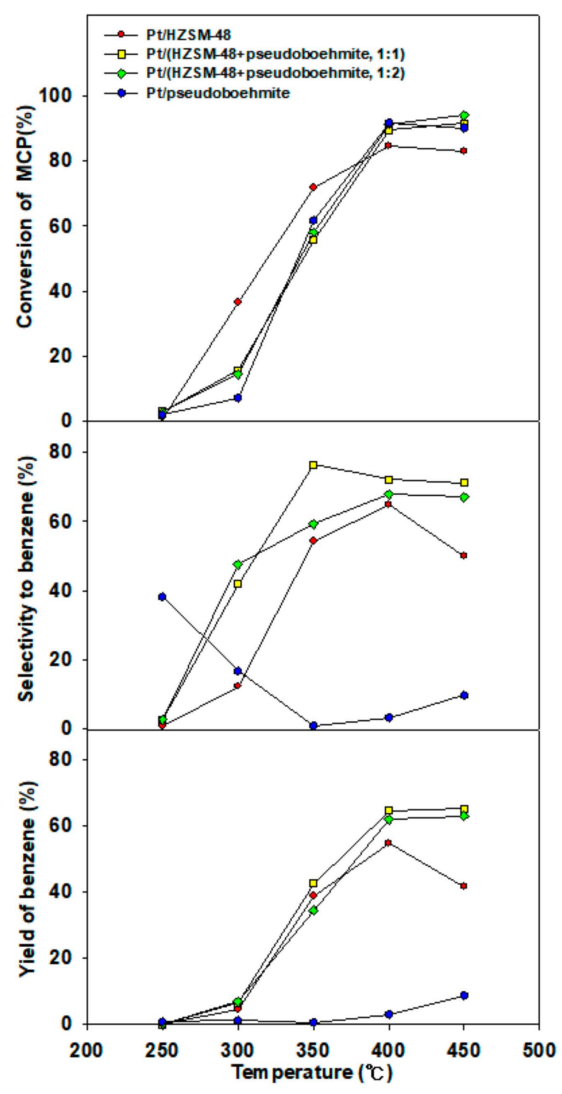

Figure 9. Effect of reaction temperature on conversion of methylcyclopentane (MCP), selectivity to benzene and yield of benzene over various catalysts (reaction condition: $\mathrm{H}_{2} / \mathrm{MCP}(\mathrm{mol} / \mathrm{mol}) 10$, pressure $1 \mathrm{~atm}$, weight hourly space velocity (WHSV) $0.3 \mathrm{~h}^{-1}$, and time-on-stream (T-O-S) $3 \mathrm{~h}$ ).

The selectivity to benzene as a function of temperature (Figure 9) increased with increasing temperature. It was noticeable that the selectivity to benzene over the Pt/(HZSM-48 + pseudoboehmite) catalysts was higher than that over the Pt/HZSM-48 catalyst. The detailed products distribution as a function of reaction temperature was exhibited in Table 3. The products in methylcyclopentane reforming can be classified into three groups: The $C_{1}-C_{5}$ fraction generated through the cracking reaction, the 2-methylpentane (2-MP) and 3-methylpentane (3-MP) synthesized through the ring opening reaction, and the benzene and cyclohexane produced through the ring enlargement reaction. It was shown that selectivity to the ring-enlargement reaction was dominant over selectivity to the ring-opening reaction over the three kinds of catalysts at a reaction temperature of $350^{\circ} \mathrm{C}$ or higher.

The selectivity to cracking increases with increasing reaction temperature from 300 to $450{ }^{\circ} \mathrm{C}$. The most notable effect of pseudoboehmite addition to the Pt/HZSM-48 catalyst was a decrease in selectivity to cracking and an increase in selectivity to benzene (Figure 10). The selectivity to the $\mathrm{C}_{1}-\mathrm{C}_{5}$ fraction over the Pt/HZSM-48, Pt/(HZSM-48 + pseudoboehmite, 1:1), and Pt/(HZSM-48 + pseudoboehmite, $1: 2$ ) catalysts at a reaction temperature of $450{ }^{\circ} \mathrm{C}$ was $25.5,10.6$, and $12.3 \%$, respectively. Meanwhile, the selectivity to benzene over the Pt/(HZSM-48 + pseudoboehmite, 1:1) and Pt/(HZSM-48 + pseudoboehmite, 1:2) catalysts was 71.1 and $67.0 \%$, respectively, which are much higher than the $50.1 \%$ over the Pt/HZSM-48 catalyst. The selectivity distinction over the three kinds of catalysts shows that the Pt/(HZSM-48 + pseudoboehmite) catalysts are better from the aspect of ring-enlargement selectivity of methylcyclopentane than the Pt/HZSM-48 catalyst. 


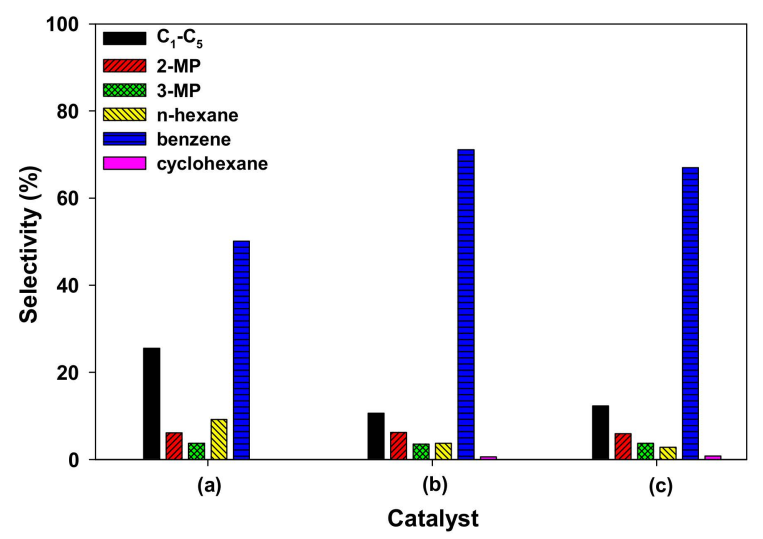

Figure 10. Product selectivity in methylcyclopentane reforming over various catalysts at a reaction temperature of $450{ }^{\circ} \mathrm{C}$. (a) Pt/HZSM-48, (b) Pt/(HZSM-48 + pseudoboehmite, 1:1), (c) Pt/(HZSM-48 + pseudoboehmite, 1:2) (reaction condition: $\mathrm{H}_{2} / \mathrm{MCP}$ (mole/mole) 10, pressure $1 \mathrm{~atm}$, WHSV $0.3 \mathrm{~h}^{-1}$, and T-O-S 3 h).

From the ring-enlargement product yield determined by the conversion of reactants and the selectivity to benzene, the benzene yield over the Pt/HZSM-48 and Pt/(HZSM-48 + pseudoboehmite) catalysts can be compared more accurately. The benzene yield over Pt/(HZSM-48 + pseudoboehmite, 1:1) was $64.6 \%$ and that over Pt/HZSM- 48 was $54.7 \%$ at $400{ }^{\circ} \mathrm{C}$ (Figure 9). The selectivity to benzene over Pt/HZSM-48 decreased at $450{ }^{\circ} \mathrm{C}$, which led to the yield of benzene over Pt/HZSM-48 decreasing to $41.6 \%$. However, the yield of benzene on $\mathrm{Pt} /(\mathrm{HZSM}-48+$ pseudoboehmite, $1: 1)$ was still about $65.1 \%$ at $450{ }^{\circ} \mathrm{C}$.

The pore diameters of the $\mathrm{Pt} /(\mathrm{HZSM}-48+$ pseudoboehmite) catalysts are much larger than those of the Pt/(HZSM-48), which benefits diffusion of ring-enlargement products in the channel of the catalyst, thereby reducing the residence time and avoiding the cracking reaction. Combined with the characteristics of the catalyst, the catalytic performance of MCP reforming is determined by acidity of the catalyst and also influenced by the pore structure of the catalyst. After pseudoboehmite addition, the acidity of Pt/HZSM-48 was modified and the selectivity of cracking products decreased on the $\mathrm{Pt} /(\mathrm{HZSM}-48$ + pseudoboehmite) catalysts. The Pt/HZSM-48 presented the highest selectivity to cracking among the three catalysts, and this may be due to the highest acidity. The selectivity of cracking products decreased after pseudoboehmite addition, which is due to the weakening of acid strength that was confirmed by $\mathrm{NH}_{3}$-TPD. Consequently, pore structure and acidity affect the reforming performance at the same time.

The effect of weight hourly space velocity (WHSV) on MCP conversion, selectivity, and yield in MCP reforming over the Pt/(HZSM-48 + pseudoboehmite, 1:1) catalyst (Figure 11) shows that increasing the space velocity from $0.3 \mathrm{~h}^{-1}$ to $2.4 \mathrm{~h}^{-1}$ resulted in a large decrease of MCP conversion. Changes in space velocity were seen to have a notable effect on the selectivity to benzene, $n$-hexane, and the $C_{1}-C_{5}$ fraction. At higher space velocities, a lower benzene content in the product resulted. In addition, a higher $n$-hexane content in the reformate was also obtained. Moreover, cracking reaction was constrained at higher space velocities because it is slower than the other reforming reactions.

The effect of the $\mathrm{H}_{2} / \mathrm{MCP}$ mole ratio on ring enlargement reaction of methylcyclopentane was investigated under atmospheric pressure, $0.3 \mathrm{~h}^{-1}$, and $450{ }^{\circ} \mathrm{C}$. Figure 12 shows that there was no significant effect on selectivity to benzene by decreasing the $\mathrm{H}_{2} / \mathrm{MCP}$ mole ratio from 10.0 to 4.0 , which is in good agreement with the results of a previous study by Lin and Gao [29]. They reported that the ring enlargement selectivity in methylcyclopentane reforming reaction over Pt/HZSM- 5 catalyst did not change significantly at a high temperature. 


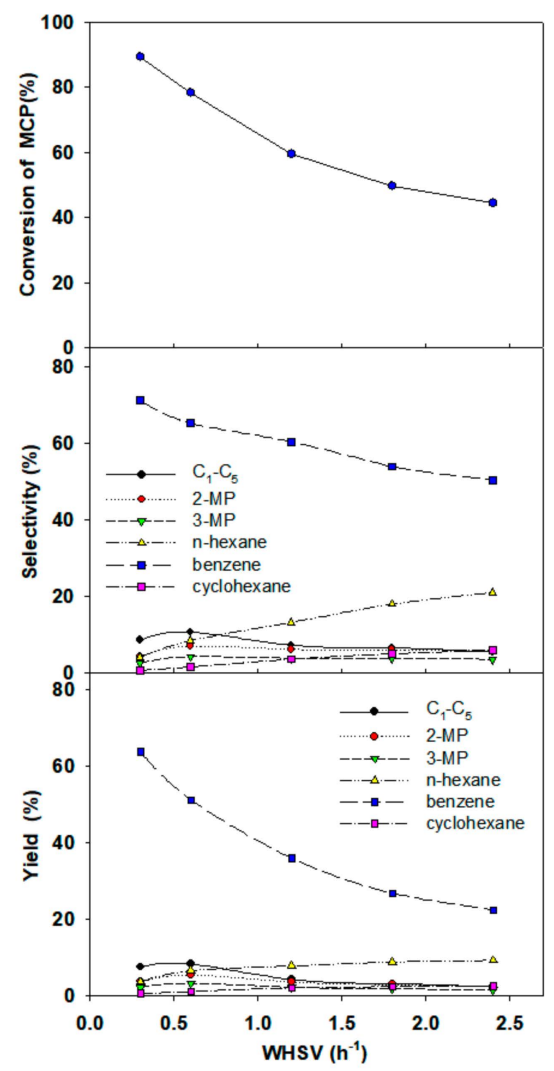

Figure 11. Effect of space velocity on conversion, selectivity and yield over $\mathrm{Pt} /(\mathrm{HZSM}-48+$ pseudoboehmite,1:1) catalyst (reaction condition: $\mathrm{H}_{2} / \mathrm{MCP}$ (mole/mole) 10, temperature $450{ }^{\circ} \mathrm{C}$, pressure $1 \mathrm{~atm}$, WHSV $0.3 \mathrm{~h}^{-1}$, and T-O-S $3 \mathrm{~h}$ ).

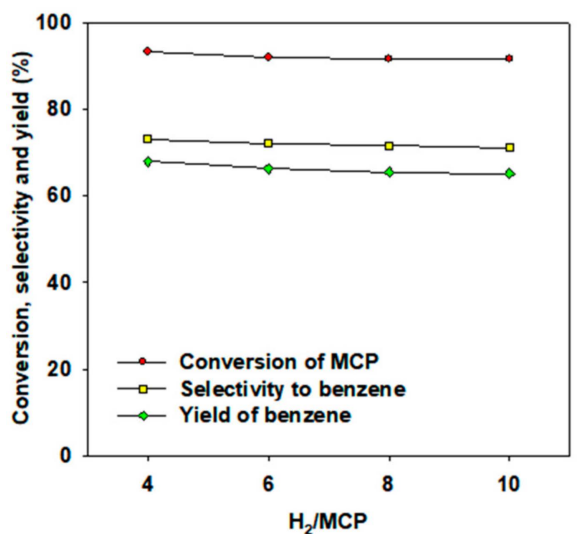

Figure 12. Effect of $\mathrm{H}_{2} / \mathrm{MCP}$ mole ratio on conversion, selectivity and yield over $\mathrm{Pt} /(\mathrm{HZSM}-48+$ pseudoboehmite,1:1) catalyst (reaction condition: pressure $1 \mathrm{~atm}$, temperature $450{ }^{\circ} \mathrm{C}, \mathrm{WHSV} 0.3 \mathrm{~h}^{-1}$, and T-O-S 3 h).

The catalysts used in this study showed good stability for methylcyclopentane ring enlargement reaction. As shown in Figure 13, the conversion of methylcyclopentane and the selectivity to benzene over the Pt/(HZSM-48 + pseudoboehmite, 1:1) catalyst did not decrease significantly during 9 h of T-O-S. To investigate the catalytic stability, the metallic Pt particle size of the spent catalyst was measured by $\mathrm{CO}$ chemisorption. The metallic Pt particle size of the spent Pt/(HZSM-48 + pseudoboehmite, 1:1) catalyst from the $\mathrm{CO}$ chemisorption increased to $6.5 \mathrm{~nm}$ compared to the metallic Pt particle size of $6.3 \mathrm{~nm}$ for the fresh catalyst, indicating that the sintering of Pt could be negligible during the MCP reforming reaction conditions. In addition, the phase transition from pseudoboehmite to aluminum 
oxide was not observed after catalytic test for $9 \mathrm{~h}$. It has been reported that the phase transformation of pseudoboehmite occurs at a temperature higher than $470{ }^{\circ} \mathrm{C}[30]$.

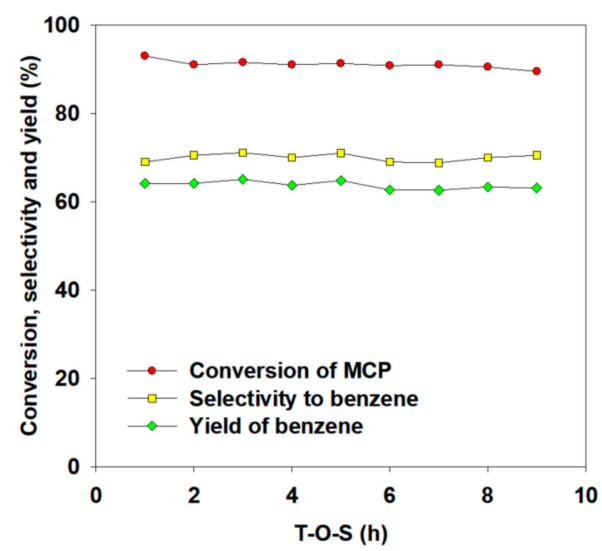

Figure 13. Conversion of MCP, selectivity to benzene and yield of benzene over Pt/(HZSM-48 + pseudoboehmite, $1: 1)$ catalyst. (reaction condition: $\mathrm{H}_{2} / \mathrm{MCP}(\mathrm{mol} / \mathrm{mol}) 10$, temperature $450{ }^{\circ} \mathrm{C}$, pressure $1 \mathrm{~atm}$, and WHSV $0.3 \mathrm{~h}^{-1}$ ).

\section{Materials and Methods}

\subsection{Synthesis of Catalysts}

HZSM-48 was prepared according to the methods reported in the literature [23]. A mixture of $0.5 \mathrm{~g}$ of $\mathrm{Al}_{2}\left(\mathrm{SO}_{4}\right)_{3} \cdot 18 \mathrm{H}_{2} \mathrm{O}$ (Sigma-Aldrich, Saint Louis, MO, USA), $135 \mathrm{~g}$ of distilled water, $1.4 \mathrm{~g}$ of $\mathrm{NaOH}$ (Sigma-Aldrich, Saint Louis, MO, USA), $4.5 \mathrm{~g}$ of hexamethonium bromide (Sigma-Aldrich, Saint Louis, MO, USA), and $9.0 \mathrm{~g}$ of fumed silica (Sigma-Aldrich, Saint Louis, MO, USA) was prepared. After mixing for $2 \mathrm{~h}$ to convert to a gel state, the mixture was placed in a $220 \mathrm{~mL}$ Teflon-lined SUS reactor (Hanul, Gunpo, Korea) and put through hydrothermal synthesis at $200{ }^{\circ} \mathrm{C}$ for $72 \mathrm{~h}$. After filtration and washing, it was dried at $100{ }^{\circ} \mathrm{C}$ for $15 \mathrm{~h}$ and calcined at $550{ }^{\circ} \mathrm{C}$ for $4 \mathrm{~h}$. Ion exchange was carried out at $85^{\circ} \mathrm{C}$ for $15 \mathrm{~h}$ using $1 \mathrm{M} \mathrm{NH}_{4} \mathrm{NO}_{3}$ (Sigma-Aldrich, Saint Louis, MO, USA) aqueous solution, and this process was repeated three times to obtain $\mathrm{NH}_{4} \mathrm{ZSM}-48$. Afterwards, the mixture was calcinated at $550{ }^{\circ} \mathrm{C}$ for $3 \mathrm{~h}$ to obtain $\mathrm{HZSM}-48$. The ratio of $\mathrm{SiO}_{2} / \mathrm{Al}_{2} \mathrm{O}_{3}$ determined using X-ray fluorescence was 32 .

Pseudoboehmite (Catapal-B) was purchased from SASOL (Sandton, South Africa). Hybrid supports were prepared by physically mixing HZSM-48 and pseudoboehmite. HZSM-48 to pseudoboehmite was mixed at mass ratios of $1: 1$ or 1:2 and used as a support. $\mathrm{H}_{2} \mathrm{PtCl}_{6}(8 \mathrm{wt} \%$ solution in water, Sigma-Aldrich, Saint Louis, MO, USA) was impregnated on the hybrid support consisting of HZSM-48 and pseudoboehmite by using the incipient wetness method. The amount of platinum loaded on the hybrid support was $0.5 \mathrm{wt} \%$. The prepared material was dried in a convection oven at $100{ }^{\circ} \mathrm{C}$ for $12 \mathrm{~h}$ and calcined at $400^{\circ} \mathrm{C}$ for $3 \mathrm{~h}$. The amount of platinum loaded on the hybrid support was $0.5 \mathrm{wt} \%$. The produced catalyst was named Pt/(HZSM- $48+$ pseudoboehmite).

\subsection{Characterization of Catalysts}

The specific surface area of the catalyst was measured using a BELSORP II (BEL Japan, Toyonaka, Japan). An amount of sample of $0.1 \mathrm{~g}$ was mounted on a cell, and the nitrogen adsorption isotherm was measured after a pretreatment process was conducted at $200^{\circ} \mathrm{C}$ for $8 \mathrm{~h}$. The specific surface area and pore size of the sample were calculated using the Brunauer-Emmet-Teller (BET) and Barrett-Joyner-Halenda $(\mathrm{BJH})$ methods, respectively. The crystal structure of the catalyst was confirmed by XRD analysis. XRD was measured at $40 \mathrm{kV}$ and $300 \mathrm{~mA}$ using a Rigaku D/MAX-2500 (Rigaku, Tokyo, Japan). The scanning electron microscope (SEM) was utilized to study the surface morphology of the catalysts using the MIRA LMH model from Tescan (Kohoutovice, Czech Republic). TEM images were collected 
using a JEM-3010 (JEOL, Tokyo, Japan) operated at $300 \mathrm{kV}$. Carbon monoxide-chemisorption analysis was carried out using a pulsed injection of $10 \%$ carbon monoxide in helium with a BELCAT-M catalyst analyzer (BEL Japan, Toyonaka, Japan).

To analyze the amount of acid sites and the acid strength of the catalyst, $\mathrm{NH}_{3}$-TPD analysis was performed using a BEL-CAT-B (BEL Japan, Toyonaka, Japan). All samples were calcined at $400^{\circ} \mathrm{C}$ for $3 \mathrm{~h}$ before $\mathrm{NH}_{3}$-TPD analysis. An amount of sample of $0.05 \mathrm{~g}$ was placed in a quartz holder and heated from room temperature to $300^{\circ} \mathrm{C}$ at a speed of $5{ }^{\circ} \mathrm{C} / \mathrm{min}$ under helium flow $(50 \mathrm{~mL} / \mathrm{min})$ for pretreatment of the sample. The sample was pretreated at $300^{\circ} \mathrm{C}$ for $1 \mathrm{~h}$. Ammonia was adsorbed at $100{ }^{\circ} \mathrm{C}$ for $30 \mathrm{~min}$ under a flow of $50 \mathrm{~mL} / \mathrm{min}$ using $5 \% \mathrm{NH}_{3} / \mathrm{N}_{2}$ gas, and then helium was flown at a rate of $50 \mathrm{~mL} / \mathrm{min}$ for $30 \mathrm{~min}$ to remove ammonia physisorbed on the sample. The helium was flown at a rate of $50 \mathrm{~mL} / \mathrm{min}$ to the sample adsorbed with ammonia, and the temperature was increased to $550{ }^{\circ} \mathrm{C}$ at a temperature rising rate of $10{ }^{\circ} \mathrm{C} / \mathrm{min}$. The desorbed ammonia was measured using a thermal conductivity detector.

To analyze the acid sites of the catalyst, pyridine-FTIR analysis was conducted using a Spectrum GX device (PerkinElmer, Waltham, MA). An amount of sample of $0.013 \mathrm{~g}$ was placed in a mold, and then a 3-ton pressure was applied to the mold to form a disk. In-situ infrared (IR) cell was fabricated from stainless steel to measure the IR spectrum at high temperature and in vacuum. For the window, $\mathrm{CaF}_{2}$ with a diameter of $20 \mathrm{~mm}$ and a thickness of $4 \mathrm{~mm}$ was used, and cooling water was flowed around the window to prevent overheating. The sample holder and the body were each made to be heated, and a temperature controller was used to program the temperature. The IR cell equipped with the sample in disk form was heated up to $300{ }^{\circ} \mathrm{C}$ in a vacuum $\left(10^{-3}\right.$ torr) and maintained at $300{ }^{\circ} \mathrm{C}$ for $1 \mathrm{~h}$. Pyridine vapor was adsorbed to the sample at room temperature for $30 \mathrm{~min}$. The IR spectrum was obtained by raising the temperature of the IR cell from $100{ }^{\circ} \mathrm{C}$ to $300^{\circ} \mathrm{C}$ under vacuum $\left(10^{-3}\right.$ torr).

\subsection{Reforming of Methylcyclopentane}

Reforming of MCP was performed in a continuous flow fixed bed reactor. The tubular reactor was made with SUS 316, and its internal diameter was $13 \mathrm{~mm}$. The reactor was heated with a cylindrical electric furnace and the temperature of the catalyst layer was adjusted by installing a thermocouple directly above the catalyst layer. After $0.75 \mathrm{~g}$ of the catalyst was installed in the reactor, reduction was performed by flowing hydrogen at $400{ }^{\circ} \mathrm{C}$ for $4 \mathrm{~h}$. The volumetric flow rate of hydrogen was controlled using the mass flow controller, and the flow rate of MCP was controlled using a syringe pump. The WHSV of the MCP and the mole ratio of $\mathrm{H}_{2} / \mathrm{MCP}$ were $0.3 \mathrm{~h}^{-1}$ and 10 , respectively. The reaction products were analyzed with a gas chromatograph (GC-6000, Younglin Instrument, Anyang, Korea) with a flame ionization detector (FID) detector. The chromatograph was loaded with a CP-Sil5 capillary column (ID $0.32 \mathrm{~mm}$, length $30 \mathrm{~m}$ with a film thickness $0.25 \mu \mathrm{m}$, Agilent, Santa Clara, CA, USA). All compounds identified in the GC-MS/FID analysis were included in the carbon balance. In the present work, the carbon balances were closed within $3.0 \%$.

\section{Conclusions}

Mesoporous structures, which resulted from mesopores of pseudoboehmite, were found to be well developed in the Pt/(HZSM-48 + pseudoboehmite) catalysts. The average size of mesopores of the $\mathrm{Pt} /(\mathrm{HZSM}-48+$ pseudoboehmite) catalysts was about $3.5 \mathrm{~nm}$. Adding pseudoboehmite to the Pt/HZSM-48 catalyst increased the total amount of acid sites and weakened the strength of acid sites. Lewis acid sites were more abundant than Brönsted acid sites over the Pt/(HZSM-48 + pseudoboehmite) catalysts.

The methylcyclopentane conversion over the Pt/(HZSM-48+pseudoboehmite) catalysts was higher than that over the Pt/HZSM-48 catalyst during reforming of methylcyclopentane. It was found that selectivity to the ring-enlargement reaction was dominant over selectivity to the ring-opening reaction over the $\mathrm{Pt} /\left(\mathrm{HZSM}-48+\right.$ pseudoboehmite) catalysts at a reaction temperature of $350{ }^{\circ} \mathrm{C}$ or higher. The benzene yield over the Pt/(HZSM- 48 + pseudoboehmite, 1:1) catalyst reached $65.1 \%$ at 
$450{ }^{\circ} \mathrm{C}$ and $0.3 \mathrm{~h}^{-1}$. As well as being influenced by the mesoporous structure, the higher activity and selectivity in MCP reforming was also determined by appropriate acidity of the Pt/(HZSM- $48+$ pseudoboehmite) catalysts.

Author Contributions: Data curation, Y.P., Y.C.K. and J.K.; Formal analysis, Y.P., Y.S.C. and J.M.K.; Funding acquisition, J.-K.J.; Methodology, J.-K.J.; Supervision, J.-K.J.; Writing-original draft, Y.P. and J.-K.J.; Writing - review \& editing, Y.-K.P., J.M.K. and J.-K.J.

Funding: This work was supported by the research grant of the Kongju National University in 2016.

Conflicts of Interest: The authors declare no conflict of interest.

\section{References}

1. Kimura, T.; Hata, N.; Sakashita, K.; Asaoka, S. Production of aromatics from heavier n-paraffins on hybrid cracking-reforming catalyst. Catal. Today 2012, 185, 119-125. [CrossRef]

2. Alayoglu, S.; Aliaga, C.; Sprung, C.; Somorjai, G.A. Size and shape dependence on Pt nanoparticles for the methylcyclopentane/hydrogen ring opening/ring enlargement reaction. Catal. Lett. 2011, 141, 914-924. [CrossRef]

3. Fechete, I.; Donnio, B.; Ersen, O.; Dintzer, T.; Djeddi, A. Applied Surface Science Single crystals of mesoporous tungstenosilicate W-MCM-48 molecular sieves for the conversion of methylcyclopentane (MCP). Appl. Surf. Sci. 2011, 257, 2791-2800. [CrossRef]

4. Teschner, D.; Paál, Z.; Duprez, D. The effects of hydrogen pressure and temperature on the methylcyclopentane conversion on Rh catalysts. Catal. Today 2001, 65, 185-190. [CrossRef]

5. Lerner, B.A.; Carvill, B.T.; Sachtler, W.M.H. Enhanced benzene formation on Pt/H-mordenite and Pd/H-mordenite. Catal. Lett. 1993, 18, 227-234. [CrossRef]

6. Martin, N.; Viniegra, M.; Lima, E. Espinosa, Coke characterization on $\mathrm{Pt} / \mathrm{Al}_{2} \mathrm{O}_{3}$-zeolite reforming catalysts. Ind. Eng. Chem. Res. 2004, 43, 1206-1210. [CrossRef]

7. Smirniotis, P.G.; Ruckenstein, E. Comparision between Zeolite $\beta$ and $\gamma-\mathrm{Al}_{2} \mathrm{O}_{3}$ supported Pt for reforming reactions. J. Catal. 1993, 140, 526-542. [CrossRef]

8. Upare, D.P.; Wee, C. Catalytic selective ring opening of methylcyclopentane in the presence of $\mathrm{CO}_{2}$. Fuel Process. Technol. 2014, 126, 243-248. [CrossRef]

9. Ajarroud, A.; Tayane, S.; Jei, T.; Bensitel, M.; Bennamara, A.; Abourrich, A. Conversion of methylcyclopentane (MCP) on Pt-Mo/ $\mathrm{AlPO}_{4}$ catalyst. In Proceedings of the Second International Conference on Smart Application and Data Analysis for Smart Cities, Casablanca, Morocco, 27-28 February 2018.

10. Zhao, Z.; Moskaleva, L.V.; Ro, N. Ring-opening reactions of methylcyclopentane over metal catalysts, M=Pt, $\mathrm{Rh}$, Ir, and Pd: A mechanistic study from first-principles calculations. ACS Catal. 2013, 3, 196-205. [CrossRef]

11. Upare, D.P.; Yoon, S.; Lee, J.H.; Lee, C.W. Ni/SiO 2 Catalyst for the selective ring opening of methylcyclopentane. Adv. Porous Mater. 2013, 1, 194-201. [CrossRef]

12. Djeddi, A.; Fechete, I. Selective ring opening of methylcyclopentane over $\mathrm{Pt} / \gamma-\mathrm{Al}_{2} \mathrm{O}_{3}, \mathrm{Ir} / \gamma-\mathrm{Al}_{2} \mathrm{O}_{3}$ and $\mathrm{Pt}-\mathrm{Ir} / \gamma-\mathrm{Al}_{2} \mathrm{O}_{3}$ catalysts with hydrogen at atmospheric pressure. Appl. Catal. A-Gen. 2012, 414, 340-349. [CrossRef]

13. Galperin, L.B.; Bricker, J.C.; Holmgren, J.R. Effect of support acid-basic properties on activity and selectivity of Pt catalysts in reaction of methylcyclopentane ring opening. Appl. Catal. A-Gen. 2003, 239, 297-304. [CrossRef]

14. Du, H.; Fairbridge, C.; Yang, H.; Ring, Z. The chemistry of selective ring-opening catalysts. Appl. Catal. A-Gen. 2005, 294, 1-21. [CrossRef]

15. Poupin, C.; Pirault-roy, L.; La, C.; Tóth, L.; Chamam, M.; Wootsch, A.; Paál, Z. Promising PtIr, catalysts for hydrocarbon transformation: Comparison of different preparation methods. J. Catal. 2010, 272, 315-319. [CrossRef]

16. Samoila, P.; Boutzeloit, M.; Especel, C.; Epron, F.; Mare, P. Selective ring-opening of methylcyclopentane on platinum-based bimetallic catalysts. Appl. Catal. A-Gen. 2009, 369, 104-112. [CrossRef]

17. Lecarpentier, S.; Van Gestel, J.; Thomas, K.; Gilson, J.; Houalla, M. Study of $\mathrm{Ir} / \mathrm{WO}_{3} / \mathrm{ZrO}_{2}-\mathrm{SiO}_{2}$ ring-opening catalysts: Part II. Reaction network, kinetic studies and structure-activity correlation. J. Catal. 2008, 254, 49-63. [CrossRef] 
18. Yin, H.; Liu, X.; Zhou, T.; Lin, A. Effect of preparation method of nanosized zeolite $\mathrm{HY}-\mathrm{Al}_{2} \mathrm{O}_{3}$ composite as NiMo catalyst support on diesel. J. Fuel Chem. Technol. 2018, 46, 950-956. [CrossRef]

19. Samoila, P.; Boutzeloit, M.; Especel, C.; Epron, F.; Marécot, P. Relationship between the structural properties of supported bimetallic $\mathrm{Pt}-\mathrm{Rh}$ catalysts and their performances for methylcyclopentane ring opening. J. Catal. 2010, 276, 237-248. [CrossRef]

20. Bakos, I.; Szabó, S.; Tóth, L.; Wild, U.; Schlögl, R.; Paál, Z. Preparation, characterization and catalytic testing of GePt catalysts. J. Catal. 2009, 263, 372-379.

21. Chamam, M.; Boghian, I. Methylcyclopentane transformation on Ge-Rh bimetallic catalysts prepared by organometallic grafting. Catal. Commun. 2007, 8, 686-692. [CrossRef]

22. Chen, C.; Ji, H.; Zhang, Q.; Li, C.; Shan, H. Effect of $\gamma$-alumina as active matrix added to HZSM-5 catalyst on the aromatization of methanol. Appl. Petrochem. Res. 2015, 5, 231-243. [CrossRef]

23. Zhang, M.; Chen, Y.; Wang, L.; Zhang, Q.; Tsang, C.W.; Liang, C. Shape selectivity in hydroisomerization of hexadecane over Pt supported on 10-ring zeolites: ZSM-22, ZSM-23, ZSM-35, and ZSM- 48. Ind. Eng. Chem. Res. 2016, 55, 6069-6078. [CrossRef]

24. Li, H.; Liu, C.; Wang, Y.; Zheng, J.; Fan, B.; Li, R. Synthesis, characterization and n-hexane hydroisomerization performances of Pt supported on alkali treated ZSM-22 and ZSM-48. RSC Adv. 2018, 8, 28909-28917. [CrossRef]

25. Thommes, M.; Kaneko, K.; Neimark, A.V.; Olivier, J.P.; Rodriguez-Reinoso, F.; Rouquerol, J.; Sing, K.S.W. Physisorption of gases, with special reference to the evaluation of surface area and pore size distribution (IUPAC Technical Report). Pure Appl. Chem. 2015, 87, 1051-1069. [CrossRef]

26. Sotomayor, F.J.; Cychosz, K.A.; Thommes, M. Characterization of Micro/Mesoporous Materials by Physisorption: Concepts and Case Studies. Acc. Mater. Surf. Res. 2018, 3, 34-50.

27. Jung, E.A.; Jeon, S.H.; Kim, C.U.; Jeong, S.Y.; Park, Y.K.; Jeon, J.K. Hydro-upgrading of n-octadecane over $\mathrm{Pt}-\mathrm{Mg} / \mathrm{HY}$ catalysts. Catal. Today 2016, 265, 124-130. [CrossRef]

28. You, Y.; Park, Y.; Han, J.; Kwon, T.S.; Seo, D.; Seong, M.; Jeon, J.K. Synthesis of exo-tricyclopentadiene from endo-dicyclopentadiene over mesoporous aluminosilicate catalysts prepared from Y zeolite. Korean J. Chem. Eng. 2019, 36, 30-36. [CrossRef]

29. Lin, W.; Gao, Z. Hydroconversion of methylcyclopentane over Pt/HZSM-5 catalyst: I. Effects of reaction parameters on ring enlargement reaction. J. Fuel Chem. Technol. 2008, 36, 449-454. [CrossRef]

30. Vieira Coelho, A.C.; Rocha, G.A.; Souza Santos, P.; Souza Santos, H.I.; Kiyohara, P.K. Specific surface area and structures of aluminas from fibrillar pseudoboehmite. Revista Matéria 2008, 13, 329-341. [CrossRef] 